\title{
The relationship between the phonological strategies employed in reading and spelling
}

\author{
Laura Huxford, Colin Terrell and Lynette Bradley
}

Cheltenham and Gloucester College of Higher Education and

University of Oxford

\section{ABSTRACT}

This paper summarises a longitudinal study which examined the relationship between the abilities of young children to read and spell phonologically. Empirical evidence of Bryant and Bradley (1980) and Cataldo and Ellis (1988) to show that children acquire the ability to use a phonological strategy for spelling before the ability to use an equivalent strategy for reading is confirmed. Implications for the teaching of reading are discussed.

\section{$R E ́ S U M E ́$}

La relation entre les stratégies phonologiques employées dans l'orthographe et dans la lecture

Cet article résume une étude longitudinale qui a examiné la relation entre les capacités dont se servent les jeunes enfants pour lire et pour orthographier de façon phonologique. On décrit le modèle développemental de Frith (1985) concernant les stratégies employées dans la lecture et dans l'orthographe. Ce modèle suppose qu'au début la capacité de lire et d'écrire dépend d'une stratégie logographique, qui est suivie d'une stratégie alphabétique (phonologique), et que la stratégie alphabétique devient utilisable dans l'orthographe plus tôt que dans la lecture. Ce reflète une recherche de Bryant et Bradley (1980) qui ont trouvé que les enfants pouvaient orthographier, mais pas lire, certains mots réguliers.

On propose qu'une évaluation du degré auquel les enfants emploient une stratégie phonologique dans l'orthographe pourrait indiquer leur potentialité pour se servir d'une stratégie semblable dans la lecture. Afin de faire une enquête sur cette possibilité dans le contexte d'autres résultats soit compatibles (Cataldo et Ellis, 
1988), soit incompatibles (Leroy-Boussion, 1975; Roberts, 1975), une étude longitudinale a été établie. Elle a employé un échantillon de 43 enfants (résultat moyen dans le British Picture Vocabulary Test (Test pictural de vocabulaire britannique): 99). On leur a donné toutes les huit semaines des tests standardisés de la lecture et de l'orthographe, et de connasissance de l'alphabet, et huit tests phonologiques spécialement préparés.

Cet article décrit deux des tests et les données que l'on a obtenu en les employant plusieurs fois avec les enfants dans l'échantillon. (Le reste des tests fonctionnaient comme contrôles pour mémoire logographique des mots, et pour la connaissance de l'alphabet.) Les enfants ont lu une liste de non-mots de deux et trois lettres à une occasion, et les ont orthographiés à une autre. Les non-mots ont été construits des lettres que l'on supposait les mieux connues chez les enfants de cet âge, et des phonèmes les plus faciles à isoler. On a introduit les non-mots comme les noms de caractères fictifs, pour rendre la tâche plausible. Le performance de chaque enfant dans les deux tâches a été comparé. Les enfants ont été retirés de l'étude dès que leur performance achevait le maximum.

Régulièrement durant toute l'étude, les enfants l'ont trouvé plus facile d'orthographier la liste de non-mots que la lire. Ce résultat est compatible avec le modèle de Frith et avec les résultats de Bryant et Bradley (1980) et de Cataldo et Ellis (1988). On peut conclure qu'il n'est pas raisonnable de s'attendre à ce que les enfants emploient une stratégie phonologique dans la lecture avant qu'ils aient de l'expérience de l'emploi d'une telle stratégie dans l'orthographe. Une étude d'intervention pédagogique serait nécessaire pour déterminer s'il y ait une relation causale entre la capacité phonologique des enfants dans l'orthographe et dans la lecture.

\section{INTRODUCTION}

Conventionally, instruction in literacy skills often started with reading. Writing was usually limited in the early stages to letter-formation and copying from a model (e.g. Mackay, Thompson and Schaub, 1970). Little emphasis used to be placed on spelling among teachers of 4-6 year old children (DES, 1975). However, there has recently been a move to encourage children to write freely at an early age and create their own forms of words (Teale and Sulzby, 1986; Clay, 1989). This may have, in part, been initiated by continuing research in children's phonological development.

Frith's model (1985), outlining the development of the strategies young children use in acquiring literacy skills, is reflected in programmes for the teaching of reading and writing (DES, 1989). She describes two strategies for the beginning reader, the 'logographic' followed by the 'alphabetic', and a further stage, the 'orthographic', for the more skilled reader. During the 'logographic' stage children read words by visual recall, being largely unable to read unfamiliar words except through intelligent contextual guessing. Knowledge of individual letters and of the sounds they represent characterises the 'alphabetic' stage. According to Frith, in addition to the visual and contextual strategies which they already employ, children at this stage use a phonological strategy to 'sound out' the letters, or letter combinations, and juxtapose them to pronounce a word not in their visual lexicon, e.g. ' $b-a-t=b a t$, ba- $t=$ bat, $b$-at $=$ bat'. Similarly, visual and phonological strategies are considered to be requisite for spelling. Although some children are able to recall some words 
visually for spelling purposes at an early age, a phonological strategy may be more productive where children can spell a word by matching letter shapes to the sounds they can perceive in the spoken word, e.g. 'day' may be written as 'DA' (Read, 1971).

Within each strategy, reading and spelling appear to be the obverse of one another. But while it is not generally expected that children, using a visual strategy, will be able to spell all the words they can read ('dinosaur' is harder to spell than to read), the same is not true of a phonological strategy. On the whole, children can spell phonologically earlier than they can read phonologically. Children can use a phonological strategy to spell a word and be unable to read that word using an equivalent strategy. Bryant and Bradley (1980) illustrated this independence of the phonological strategies. They asked children to read and spell the same list of words on different occasions. Four categories of words emerged from this exercise. As might be expected, some words were both read and spelled correctly while others were neither read nor spelled. Some words, typically 'school', 'light', 'train' and 'egg', were read but not spelled, presumably being recognised as sight-words but not retained, in memory, for spelling purposes. The last group of words, represented by 'bun', 'mat', 'leg' and 'pat' were spelled but not read. The assumption here is that the children could not read them as sight words or phonologically, but their attempts at spelling the words phonologically proved accurate because those particular words contained direct phoneme-grapheme correspondences. The authors suggest that children may rely on a phonological strategy for spelling before they are able to do so for reading.

If children can spell phonologically before they read phonologically the impiications are far-reaching. It has been shown that when children start to spell phonologically they are only able to identify, correctly, the first letter of the word they wish to write. For instance, in writing the word 'stand', a first attempt would most likely be the letter ' $s$ '. At the next stage, the final consonant may be added, making 'sd'. Next, the addition of the vowel will produce 'sad' and later, further consonants will result in the conventional spelling of 'stand' (Read, 1971; Clay, 1989; Ellis, 1989). It should be possible from an assessment of children's phonological spelling to ascertain their potential for starting to employ a phonological strategy for reading. This kind of assessment could prevent children being expected to read a word by 'sounding out' before their phonological awareness is sufficiently heightened.

Recently, a study by Cataldo and Ellis (1988) has suggested that 'experience in spelling promotes the use of a phonological strategy in reading' (page 86), supporting the results of a training study by Ehri and Wilce (1987). On the other hand, earlier experimental work on phonological analysis and synthesis would suggest that a phonological reading strategy is probably acquired before an equivalent spelling strategy (Roberts, 1975; Leroy-Boussion, 1975). In order to examine the relationship between the phonological strategies children use for reading and spelling further, a longitudinal study was established.

\section{METHOD}

\section{Subjects}

The 43 children in the study came from the reception classes of two Primary schools. The majority of the children entered the study at four or five years of age and were 
tested at eight-week intervals. The number of tests for each child depended on how quickly a child achieved ceiling level on the phonological tasks because at this point testing was discontinued. The mean age of these children at final testing was 5 years 5 months (SD 8 months; range: 4 years 3 months-6 years 10 months). Their mean score on British Picture Vocabulary Scales (BPVS) (Dunn et al., 1982) was 99 (SD 14.9).

\section{Tests and Procedures}

A combination of standardized tests and tasks specifically devised and refined for the study have been used. A battery of eight tests was constructed to compare reading and spelling, controlling for alphabet and use of visual and contextual strategies. In order to assess children's phonological development against other factors of experience and ability, measures of age, reading, spelling, alphabetical knowledge, intelligence, memory and hearing were taken. The phonological tests devised for this study consisted of two reading and spelling tests, using non-words, supported by two others using real words and four phonological segmentation and blending tests. The six supporting tests were used to control for variables such as the children's alphabetic knowledge and are not described in detail here. The phonological spelling/reading test consisted of a list of two- and three-letter nonwords to be read on one occasion and spelled on another. As the children were only four or five years old at the beginning of the study they were asked to make the words using lower-case plastic letters instead of writing them. Non-words were used so that no strategy, other than a phonological one, could be employed in either the reading or spelling tasks. The non-words were introduced as names of fictitious characters to make the tasks meaningful.

As it was thought that some letters were easier to hear within words than others (Coleman, 1970), ' $m$ ', ' $n$ ', ' $w$ ', ' $r$ ' and ' $l$ ' were not used in the construction of the words. Furthermore a pilot study supported Stuart's results (1987), and confirmed that the letters ' $k$ ' and ' $z$ ' were as familiar to young children as much more frequently used letters in the English language, while ' $u$ ' was one of the last letters to be learned. These factors were taken into account in the construction of the non-words. Using less common letters such as ' $j$ ', ' $k$ ' and ' $z$ ' reduced the number of words which contained familiar visual letter-strings but resulted in words which are illegal in English orthography (see Appendix). The assumption was made that this would not have a detrimental effect on the children's emerging knowledge of English orthography as the words were clearly used as names, similar to 'Daz' as the brand name of a washing powder. To exclude the possibility of letter-order effects, the words were constructed using the same letters in two directions, e.g. 'zep' and 'pez'. It was decided to limit the length of the words to two and three letters as only the earliest stages in phonological spelling and reading were being examined. It is considered that consonant clusters such as those at the beginning and end of 'stand' are a later acquisition (Marcel, 1980; Treiman, 1985).

Three parallel lists (Appendix 1) were constructed to reduce practice effects. In order to minimize test-order effects half the children were presented with the reading test followed by the spelling test, and the other half, vice-versa. The children were tested individually within a game-like format. There were three practice items. Encouragement but no feedback was given during testing. 
Reading Test The child was shown a non-word on a card and asked to read it.

Spelling Test The child was presented with an array of lower-case plastic letters and was asked to select the correct letters to make a non-word spoken by the tester.

The child scored one point for each correct answer. The non-words were constructed to allow for this simple scoring system. For instance, only short vowels were used. If in the reading test children offered a long vowel, they were asked whether they knew another sound for that letter and then given a further opportunity to read the word. Marks were given for 'short vowel' answers only. Similarly, in the spelling condition, children sometimes said the correct sound but used the wrong letter to represent it. Marks were therefore not awarded. Measurements of the children's phonological knowledge and letter recognition were taken to assess the effect of letter knowledge on children's ability to use a phonological strategy for reading and spelling.

Eight weeks later the children were tested again. In subsequent sessions, the order of presentation of the reading and spelling tasks was varied systematically. Testing sessions continued at approximately eight-week intervals until each child had reached near perfect scores on both the reading and the spelling tests.

\section{RESULTS}

At the first test session the majority of children's scores were at or near floor level. Some children achieved ceiling level scores at the second testing session, eight weeks later, whereas others required over a year to progress to an equivalent level. The average length of time taken was twenty-eight weeks. Some children, therefore, took part in just two test sessions, while from the others up to six pairs of scores were obtained between initial and final testing. Readings were taken from plots of each child's results at selected, fixed points (25th, 50th and 75th quartiles) in an attempt to track developmental progress. The means of the scores at initial and final testing and each of these three intermediary levels are shown in Table 1.

Mean spelling scores were consistently higher than reading scores. When subjected to a correlated t-test the difference between the scores was significant $(p<0.001$, df 42) at each occasion of testing. A similar trend, though less dramatic, was observed in tests, administered at the same time, in which phonological segmentation scores were higher than those for blending.

Table 1. Mean scores in phonological spelling and reading, at initial test, $25 \mathrm{th}$, 50th, and 75th quartiles and final test. Maximum score $=12$ in both reading and spelling.

\begin{tabular}{lcc}
\hline Developmental Stage & Spelling & Reading \\
\hline Initial test & 2.18 & 0.18 \\
$25 \%$ & 4.11 & 1.31 \\
$50 \%$ & 6.21 & 2.66 \\
$75 \%$ & 8.15 & 4.66 \\
Final test & 11.50 & 8.58 \\
\hline
\end{tabular}




\section{DISCUSSION}

These results confirm those of Bryant and Bradley (1980) and Cataldo and Ellis (1988). Phonological spelling appears to precede phonological reading. As phonological segmentation seems to be easier than blending, it may be assumed that the apparent difference between spelling and reading ability is independent of alphabetic knowledge. For instance, at one point in their progress in the study, most children were able to give the sounds of the letters in the words they were asked to read but unable to connect the letters in order to read the words. If children cannot spell phonologically, they will be unable to read phonologically. A child's ability to spell phonologically does not indicate an ability to read phonologically although the progression found in the sample would suggest that it would not be inappropriate to begin to encourage the use of a phonological strategy for reading at this stage. There is, however, no causal connection shown in this study between the abilities of spelling and reading. It would be inaccurate to suggest, from these results, that practice in phonological spelling would advance the ability to read phonologically. Such conclusions could more validly be drawn from an intervention study within a longitudinal study and may provide further teaching implications.

\section{ACKNOWLEDGEMENT}

We are very grateful to the teachers and children at Park Infants' School, Stonehouse, Gloucestershire and Minchinhampton Parochial School, Gloucestershire.

\section{REFERENCES}

BRYANT, P. E. and BRADLEY, L. (1980) Why children sometimes write words which they do not read. In U. Frith (ed.) Cognitive Processes in Spelling. London: Academic Press.

CATALDO, S. and ELLIS, N. (1988) Interaction in the development of spelling, reading and phonological skills. Journal of Research in Reading, 11, 86-109.

CLAY, M. (1989) Writing Begins at Home. Auckland: Heinemann.

COLEMAN, E. B. (1970) Collecting a data base for a reading technology. Educational Psychology Monographs, 61, 1-23.

DEPARTMENT OF EDUCATION AND SCIENCE (1975) A Language for Life. London: HMSO.

DEPARTMENT OF EDUCATION AND SCIENCE (1989) English 5-11. London: HMSO.

DUNN, L. M., DUNN, L. M., WHEITON, C. and PINTILLIE, D. (1982) British Picture Vocabulary Scale. Windsor:

The NFER-Nelson Publishing Co Ltd.

EHRI, L. C. and WILCE, L. S. (1987) Does learning to spell help beginners learn to read words? Reading Research Quarterly, 22, 47-65.

ELLIS, N. (1989) Early Interactions in the development of reading, spelling and phonological skills. Paper presented at the Rodin Remediation Academy Conference, Bangor.

FRITH, U. (1985) Beneath the surface of developmental dyslexia. In K. E. Patterson, J. C. Marshall and M. Coltheart (eds.) Surface Dyslexia. London: Lawrence Erlbaum Ass. Ltd.

LEROY-BOUSSION, A. (1975) Une habileté auditivo-phonétique nécessaire pour apprendre à lire: la fusion syllabique. Nouvelle étude génétique entre 5 et 8 ans. Enfance, 1, 165-190.

MACKAY, D., THOMPSON, B. and SCHAUB, P. (1970) Breakthrough to Literacy: Programme in Linguistics and English Teaching. London: Schools Council/Longman.

MARCEL, A. J. (1980) Phonological awareness and phonological representation: investigation of a specific spelling problem. In U. Frith (ed.) Cognitive Processes in Spelling. London: Academic Press Inc. 
READ, C. (1971) Preschool children's knowledge of English phonology. Harvard Educational Review, 41, $1-34$.

ROBERTS, T. (1975) Skills of analysis and synthesis in the early stages of reading. British Journal of Educational Psychology, 45, 3-9.

STUART, K. M. (1987) Phonological awareness, letter-sound knowledge, and learning to read. Unpublished $\mathrm{PhD}$ Thesis. University of London.

TEALE, W. H. and SULZBY, E. (1986) Emergent Literacy: Writing and Reading. New Jersey: Ablex Publishing Corporation.

TREIMAN, R. (1985) Phonemic awareness and spelling: children's judgements do not always agree with adults. Journal of Experimental Child Psychology, 39, 182-201.

\section{APPENDIX}

Parallel lists of non-words used in the phonological reading and spelling tests

$\begin{array}{rrr}\text { ki } & \text { ke } & \text { ko } \\ \text { ep } & \text { op } & \text { ip } \\ \text { ja } & \text { ji } & \text { ze } \\ \text { ik } & \text { ek } & \text { ok } \\ \text { pe } & \text { po } & \text { pi } \\ \text { aj } & \text { ij } & \text { ez } \\ \text { pez } & \text { tov } & \text { kiz } \\ \text { vok } & \text { zet } & \text { pev } \\ \text { taz } & \text { kav } & \text { toz } \\ \text { zep } & \text { vot } & \text { zik } \\ \text { kov } & \text { tez } & \text { vep } \\ \text { zat } & \text { vak } & \text { zot }\end{array}$

Address for Correspondence: LAURA HUXFORD, Cheltenham and Gloucester College of Higher Education, The Park, Cheltenham GL50 2QF, UK. 